\title{
Adsorption of humic acid on mesoporous carbons prepared from poly- (ethylene terephthalate) templated with magnesium compounds
}

\author{
Justyna Karolczyk, Sylwia Mozia, Antoni W. Morawski, Jacek Przepiórski* \\ West Pomeranian University of Technology, Szczecin, Institute of Chemical and Environmental Engineering, ul. Pułaskiego 10, \\ 70-322 Szczecin, Poland \\ "Corresponding author: e-mail: jacek.przepiorski@zut.edu.pl
}

\begin{abstract}
Porous carbons obtained from poly(ethylene terephtalate) contained in a mixture with either $\mathrm{MgCO}_{3}$ or $\mathrm{Mg}(\mathrm{OH})_{2}$ were examined as adsorbents for removal of humic acid from water. Adsorption of the model contaminants is discussed in relation to the textural parameters of the obtained carbon materials. Pore structure parameters of the carbonaceous materials were strongly influenced by preparation conditions including temperature and relative amounts of the inorganics used during preparations as template. Porous carbons prepared revealed a potential to purify water from the model contaminant of high molecular weight. The results presented confirmed a key role of mesoporosity in the adsorption of humic acid. Fluorescence spectroscopy was confirmed to be an useful method to evaluate concentration of humic acid in water.
\end{abstract}

Keywords: porous carbon, adsorption, humic acid, fluorescence spectroscopy.

\section{INTRODUCTION}

Humic acid (HA) is a component of wide gamut of humic substances which represents a highly heterogeneous mixture of organic materials, developed during long process of decay of plants and animals ${ }^{1,2}$. HA in water is a source of unpleasant taste and colour ${ }^{3,4}$ that are undesirable in raw waters subjected to treatments aimed to produce water to be used in households or in industry. In addition, HA has been recognized as a precursor of trihalomethanes (THMs) $)^{3-5}$ formed during chlorination of water, and these are classified as carcinogenic compounds. Removal of HA from water can be a difficult process. For that reason conventional methods used for water treatment, such as coagulation, precipitation and filtration, can be not enough efficient to achieve desired degree of HA removal ${ }^{6,7}$.

Modern water treatment plants more and more commonly employ filtration with microporous activated carbons. Large adsorption efficiency revealed by these adsorbents is linked to their well-developed pore structure $^{7-9}$. Adsorption has been known as an efficient to eliminate from water mainly organic contaminants of a low molecular weight ${ }^{10-12}$. Nevertheless, much concern has been raised about effective adsorption of large molecules like humic acid ${ }^{7,13,14}$. Numerous investigations have been conducted to evaluate HA removal using various adsorbents including also activated carbons ${ }^{5,15-20}$. It's known that humic substances reveal high molecular weight ${ }^{7,21}$ and micropores present in activated carbons are inaccessible to humic acid ${ }^{22}$. For that reason, efficient adsorption of HA demands a material with a well-developed mesoporous texture. There is a number of works dealing with preparations of porous carbons rich in mesopores. A method of obtaining mesoporous activated carbon from calcium and iron-loaded bituminous coals was proposed by Lorenc-Grabowska et $\mathrm{al}^{7}$. The authors confirmed considerable adsorption of HA by the obtained carbons. Porous carbons rich in mesopores were obtained from various synthetic precursors using so called templating method ${ }^{23}$. An interesting scheme employing commercial silica sol particles as template was proposed by Han et $\mathrm{al}^{24}$. It was proven, that obtained highly mesoporous carbon materials exhibited high adsorption capacity towards humic acid. Recently much attention has been paid to use of magnesium compounds as agents capable to create mesopores in carbon materials ${ }^{23}$. Carbon precursors usually used to obtain mesoporous carbons were poly(vinyl alcohol) 23,25 $^{33}$, pitches $^{26,27}$, poly(ethylene terephthalate) $)^{23,28-32}$, wood ${ }^{33,34}$, shells wood ${ }^{35,36}$. Magnesium compounds used the preparations were $\mathrm{MgO}^{23,29,30}$, magnesium acetatae ${ }^{23,37}$, and magnesium citrate ${ }^{23,37,38}$. Recently, we have developed a new one-step method to produce porous carbon materials of bimodal character, i.e. revealing considerable volumes of both micropores and mesopores ${ }^{29-32}$. Preparation of the material consisted in carbonization of a polymeric precursor, poly(ethylene terephthalate) (PET), contained in a mixture with either light basic magnesium carbonate $\left(3 \mathrm{MgCO}_{3} \cdot \mathrm{Mg}(\mathrm{OH})_{2} \cdot 3 \mathrm{H}_{2} \mathrm{O}\right)^{29,30,32}, \mathrm{MgO}^{29-32}, \mathrm{MgCO}_{3}{ }^{30,31}$ or $\mathrm{Mg}(\mathrm{OH})_{2}{ }^{30,32}$, followed by washing out remained inorganics from obtained composite product. In this way, highly mesoporous-microporous carbon materials could be obtained without any activation process. In the previous paper ${ }^{30}$, the adsorption of contaminants of various molecular sizes, including phenol and exemplary dyes, on the obtained activated carbons was studied. As found the contaminants of a high molecular weight like dyes could be effectively removed from water using obtained porous carbons and mesoporosity played a key role during the removal process. On the other hand adsorption of phenol on the studied carbons was found to be strongly dependent on microporosity. Thus the carbons were recognized to be useful materials for adsorption of various species from water. In order to widen spectrum of potential applications of the carbons prepared, we examined adsorption of common contaminant of natural waters, HA. For that purpose a number of HA adsorption tests were carried out using carbon materials prepared and the effect was discussed in relation to the textural properties the adsorbents. Besides that, we tried to recognize suitability of fluorescence spectroscopy for evaluation of contents of humic substances in water. 


\section{EXPERIMENTAL}

\section{Materials and preparations}

Magnesium carbonate $\left(\mathrm{MgCO}_{3}\right)$ used in this study was of analytic grade (Sigma-Aldrich , Germany), and magnesium hydroxide $\left(\mathrm{Mg}(\mathrm{OH})_{2}\right)$ (Fluka, Germany) was of reagent grade $(95 \%)$. Poly(ethylene terephthalate) (PET) was of commercial grade purchased from Elana S.A. (Poland). All the preparations were carried out under high purity (99.999\%) argon gas (Messer, Austria). Leonardite humic acid (IS104H standard, purchased from the International Humic Substances Society, IHSS) was used as a model adsorbate to evaluate performance of the obtained porous carbons. According to the supplier's data, the elemental composition the model contaminant is as following: $63.81 \mathrm{wt} . \% \mathrm{C}, 3.70 \mathrm{wt} \% \mathrm{H}, 31.27$ wt. $\%$ O, 1.23 wt. $\%$ N, 0.76 wt $\%$ S, < $0.01 w t . \% ~ P$, and 2.58 wt. $\%$ ash.

Porous carbon materials used in this study were prepared according to the procedure described in details in our earlier paper $^{\mathbf{3 0}}$. Ground PET material was thoroughly mixed with either $\mathrm{MgCO}_{3}$ or $\mathrm{Mg}(\mathrm{OH})_{2}$ at three weight ratios, 30:70, 50:50, 70:30 and subjected to primary heating to $265^{\circ} \mathrm{C}$ in air atmosphere. After this step, obtained solids were heated up to $550^{\circ} \mathrm{C}$ or $850^{\circ} \mathrm{C}$ under argon gas flow. After the heating, the $\mathrm{MgO}$ formed from the inorganics used during preparations was removed from the products by mean of washing out with $\mathrm{HCl}$ solution. The solid residue obtained in this way was dried in air. The textural properties of the obtained carbon materials were determined from $\mathrm{N}_{2}$ adsorption/desorption (at 77 $\mathrm{K}$ ) isotherms. Prior to the exposition to the adsorbate gas, attained samples were outgassed at $290^{\circ} \mathrm{C}$ for $24 \mathrm{~h}$ under high vacuum. Detailed information concerning methods used to estimate the surface areas and pore volumes was given in previous article ${ }^{30}$. Specific values concerning researched materials are listed in the Table 1 and were taken from the same work.

Total organic carbon contents and fluorescence spectra

After filtering out the powdered adsorbent material, obtained filtrates were subjected to the total organic carbon (TOC) content measurements using TOC analyzer
(Multi N/C 3100, Analytic Jena, Germany). Additionally, fluorescence spectra of humic acid in the filtrates were recorded using Hitachi F-2500 spectrofluorimeter. The apparatus operated at excitation wavelength range of 350-650 $\mathrm{nm}$ and the bandwidth between the excitation and emission monochromators was $\Delta \lambda=18 \mathrm{~nm}$. Detailed description of the measurement method is given elsewhere ${ }^{39,40}$.

\section{Adsorption of humic acid onto researched porous car- bon materials}

$1 \mathrm{~g}$ of the commercial IS104H standard was dispersed in $1 \mathrm{dm}^{3}$ of ultrapure water. Additionally, in order to increase solubility of the HA, small amount (to achieve constant $\mathrm{pH}=6.9$ ) of $1 \mathrm{M} \mathrm{NaOH}$ solution was dropped into the raw suspension. After 7 days of continuous stirring the suspension was filtered through $0.45 \mu \mathrm{m}$ membrane filter and thus a raw HA solution was obtained. For the adsorption tests, the raw solution was diluted with ultrapure water to achieve TOC content $15.31 \mathrm{mg} / \mathrm{dm}^{3}$ in the obtained working solution. Adsorption of HA was carried out using 5 to $50 \mathrm{mg}$ of the studied adsorbent materials suspended in $250 \mathrm{~cm}^{3}$ of the working HA solution. The suspensions were agitated in a thermostated $\left(30^{\circ} \mathrm{C}\right)$ water bath for 48 hours and then TOC contents in the liquid phases were measured. In addition fluorescence spectra of the liquid phase were recorded.

\section{RESULTS AND DISCUSSION}

The results collected during a series of TOC removal tests performed for the studied carbon materials obtained from poly(ethylene terephthalate) in the presence of magnesium compounds including carbonate and hydroxide, are presented in Figure 1.

In general, all the examined adsorbents reveal a potential to remove humic acid from water and adsorption abilities towards the contaminant vary with loading of magnesium compounds in the raw mixtures with PET used for preparations. In view of results collected for the materials obtained at 550 and $850^{\circ} \mathrm{C}$ from raw mixtures loaded with the largest amounts of inorganics, influence of preparation temperature on the performance of resultant carbon materials is also very clear. It's well known that

Table 1. Textural characteristics of activated carbons obtained from PET mixed with magnesium carbonate $\left(\mathrm{MgCO}_{3}\right)$ or magnesium hydroxide $\left(\mathrm{Mg}(\mathrm{OH})_{2}\right)$

\begin{tabular}{|c|c|c|c|c|c|c|c|}
\hline & \multirow{2}{*}{$\begin{array}{c}\mathrm{S}_{\mathrm{BET}} \\
{\left[\mathrm{m}^{2} / \mathrm{g}\right]}\end{array}$} & \multicolumn{3}{|c|}{$\alpha_{s}$ analysis } & \multirow{2}{*}{$\begin{array}{l}V_{\text {tot } 0.95} \\
{\left[\mathrm{~cm}^{3} / \mathrm{g}\right]}\end{array}$} & \multirow{2}{*}{$\begin{array}{l}V_{\text {microDR }} \\
{\left[\mathrm{cm}^{3} / \mathrm{g}\right]}\end{array}$} & \multirow{2}{*}{$\begin{array}{l}V_{\text {meso }} \\
{\left[\mathrm{cm}^{3} / \mathrm{g}\right]}\end{array}$} \\
\hline & & $\begin{array}{c}S_{\text {total }} \\
{\left[\mathrm{m}^{2} / \mathrm{g}\right]}\end{array}$ & $\begin{array}{c}S_{\text {ext }} \\
{\left[\mathrm{m}^{2} / \mathrm{g}\right]}\end{array}$ & $\begin{array}{l}\mathrm{S}_{\text {micro }} \\
{\left[\mathrm{m}^{2} / \mathrm{g}\right]}\end{array}$ & & & \\
\hline \multicolumn{8}{|l|}{$\mathrm{MgCO}_{3} / \mathrm{PET}^{\mathrm{a}}$} \\
\hline $30 / 70,850^{\circ} \mathrm{C}$ & 870 & 986 & 712 & 274 & 1.34 & 0.37 & 0.97 \\
\hline $50 / 50,850^{\circ} \mathrm{C}$ & 1118 & 1189 & 852 & 337 & 1.97 & 0.46 & 1.51 \\
\hline $70 / 30,550{ }^{\circ} \mathrm{C}$ & 953 & 919 & 733 & 186 & 1.21 & 0.38 & 0.83 \\
\hline $70 / 30,850^{\circ} \mathrm{C}$ & 1772 & 1756 & 1518 & 238 & 3.35 & 0.69 & 2.66 \\
\hline \multicolumn{8}{|l|}{$\mathrm{Mg}(\mathrm{OH})_{2} / \mathrm{PET}^{\mathrm{a}}$} \\
\hline $30 / 70,850^{\circ} \mathrm{C}$ & 907 & 1008 & 622 & 385 & 1.70 & 0.38 & 1.32 \\
\hline $50 / 50,850^{\circ} \mathrm{C}$ & 1049 & 1124 & 776 & 348 & 2.23 & 0.43 & 1.80 \\
\hline $70 / 30,550{ }^{\circ} \mathrm{C}$ & 875 & 836 & 643 & 193 & 1.34 & 0.36 & 0.98 \\
\hline $70 / 30,850^{\circ} \mathrm{C}$ & 1302 & 1317 & 1019 & 298 & 2.03 & 0.52 & 1.51 \\
\hline
\end{tabular}

${ }^{a}$ data collected from ${ }^{30}$ 

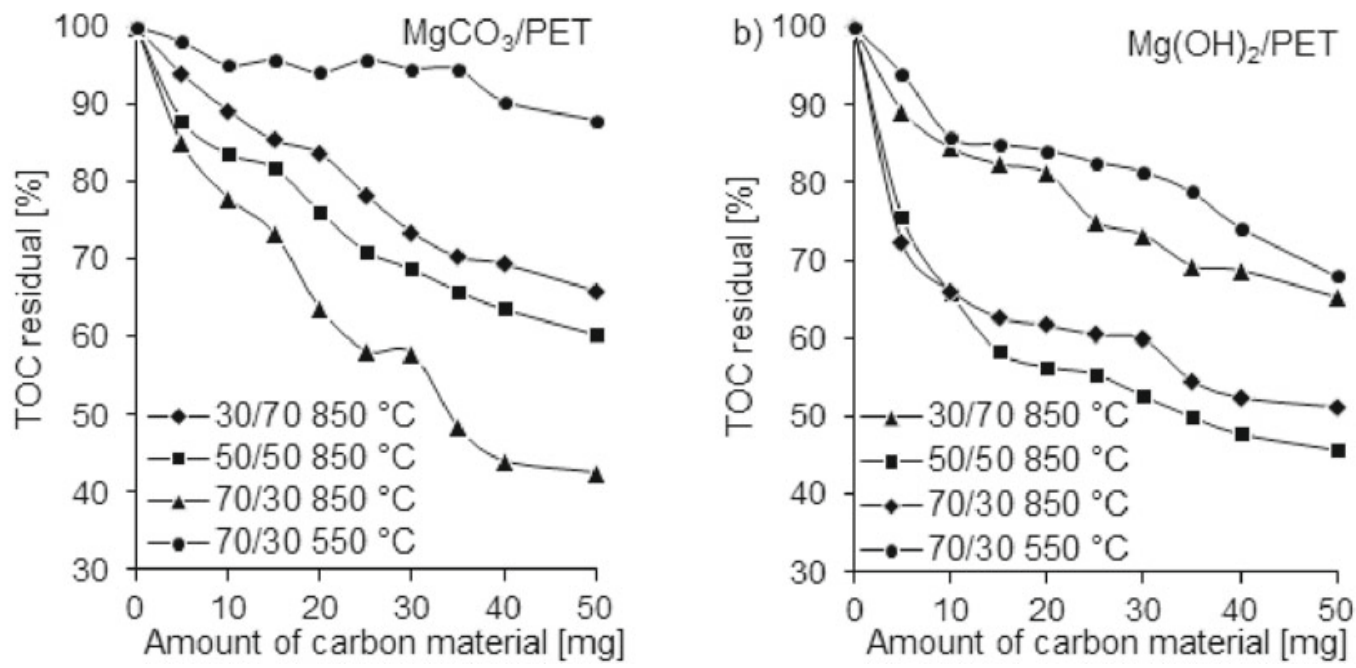

Figure 1. Adsorption of $\mathrm{HA}$ from water on carbon materials obtained from a) $\left.\mathrm{MgCO}_{3} / \mathrm{PET}, \mathrm{b}\right) \mathrm{Mg}(\mathrm{OH})_{2} / \mathrm{PET}$ with different weight ratio at 550 and $850^{\circ} \mathrm{C}$

adsorption of humic substances demands a material with a well-developed mesoporous texture and this is due to large molecular sizes of the adsorbates ${ }^{41}$. As listed in Tab. 1, the carbon materials prepared from PET with use of either $\mathrm{MgCO}_{3}$ or $\mathrm{Mg}(\mathrm{OH})_{2}$ exhibit considerable mesoporosity that varies with (Mg compound)/PET ratio and additionally depends on the preparation temperature. For that reason the mesoporosity was considered as the key factor affecting removal of HA from water. Regardless of the kind of magnesium compound used for preparations, performance of the carbons prepared at lower temperature $\left(550^{\circ} \mathrm{C}\right)$, has been recognized as relatively low, achieving $12-32 \%$ TOC removal. In view of data contained in Tab. 1, this must be related to the lowest pore structure parameters including pore volumes and surface areas, revealed by these carbons. In contrast, the highest surface areas and pore volumes determined for the carbon prepared from $\mathrm{MgCO}_{3} / \mathrm{PET}$ (70/30) mixture at $850^{\circ} \mathrm{C}$, seem to be the reason why performance of the adsorbent is higher compared to the others, reaching ca. 57\% removal of TOC.

Results collected for the porous carbons prepared using $\mathrm{Mg}(\mathrm{OH})_{2} / \mathrm{PET}$ mixtures do not fully comply with observations valid for the other system employing $\mathrm{MgCO}_{3}$ for preparations. So, despite the lower $\mathrm{Mg}(\mathrm{OH})_{2} / \mathrm{PET}$ ratio (50:50), obtained carbon performs little more efficiently compared to that prepared from the mixture richer in magnesium hydroxide. Such a trend again seems to be related to the porosity of the studied adsorbents. Hence, even the $\mathrm{Mg}(\mathrm{OH})_{2} / \mathrm{PET}$ (70:30) - based carbon exhibits relatively high surface areas, mesopore volume determined for the carbon prepared from the equivalent $\mathrm{Mg}(\mathrm{OH})_{2} / \mathrm{PET}$ mixture, $50: 50$, reaches $1.80 \mathrm{~cm}^{3} / \mathrm{g}$. This is the highest value among mesopore volumes determined for samples from this series. Observed trends remain in agreement with results reported by others ${ }^{42,43}$ pointing mesopore volume as a key factor influencing amount of humic substances adsorbed on the porous surface.

Appropriate fluorescence spectra measured for the working HA solution and for liquids remained after the adsorption tests performed for several adsorbents are presented in Fig. 2. All the recorded spectra reveal two bands, less intensive one at around $350-400$ $\mathrm{nm}$ and more distinct one at around $450-500 \mathrm{~nm}$. The fluorescence band located at longer wavelengths, ca. 470 $\mathrm{nm}$, corresponds to effects resulting from a presence of polycyclic aromatics consisting of seven fused benzene rings ${ }^{39}$. On the other hand, the bands revealing maxima at around $380 \mathrm{~nm}$ are attributed to the fluorescence from structures of relatively low molecular weight, normally contained in humic substances like $\mathrm{HA}^{44-46}$. Apparently, the spectrum measured for the fresh working HA solution is of the highest intensity. However, intensities of both fluorescence bands are evidently reduced in the spectra collected for the HA solutions after the adsorption tests. This distinct decrease confirms capability of the studied carbon materials to remove from water humic substances of various molecular weights.

Intensities of fluorescence from HA contained in waters subjected to the adsorption tests steadily decrease in order analogous to that as already discussed for TOC removal. Hence, the most effective removal of the humic substances can be seen in the presence of carbon samples prepared at $850^{\circ} \mathrm{C}$ and from PET in mixtures rich in magnesium compounds. This can be attributed to the favorable for HA removal pore structure exhibited by these sorbent material.

\section{CONCLUSIONS}

The present paper was undertaken to investigate the suitability of carbon materials obtained from PET in mixture with either $\mathrm{Mg}(\mathrm{OH})_{2}$ or $\mathrm{MgCO}_{3}$ for removal of humic substances from water. Obtained results confirmed a strong correlation between the textural parameters, especially mesopore volume, of the studied adsorbents and the uptake of humic acid from water. Because of a good consistence with results of TOC removals tests, we propose fluorescence spectroscopy as a suitable alternate tool to evaluate performance of carbons during removal of humic acid from aqueous solutions. However, in order to estimate the extent of the removal quantitatively, there is a necessity to determine dependence between the humic acid content and the fluorescence intensity.

\section{Acknowledgement}

This work was financed by the Polish Ministry of Science and Higher Education, Grant No. N R050004 10. 

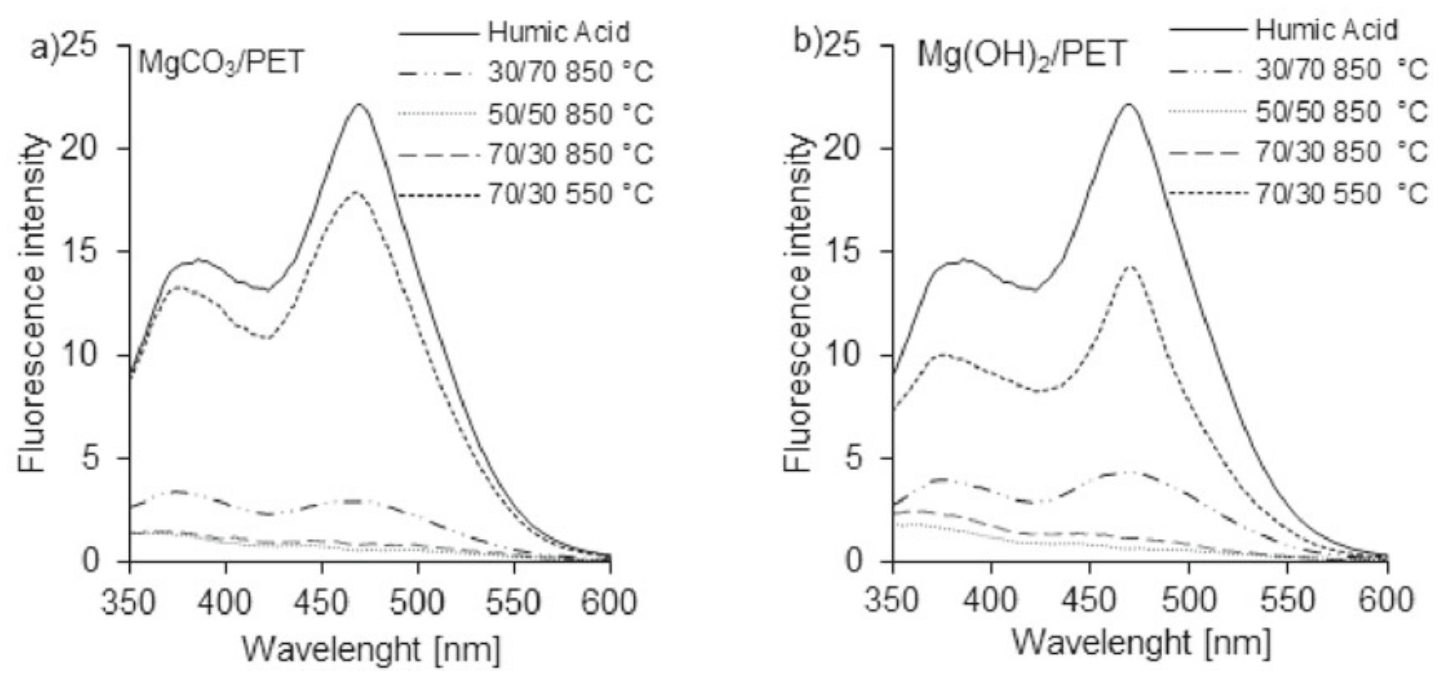

Figure 2. Synchronous fluorescence spectra recorded for the working HA solution and after adsorption test using porous carbons prepared from a) $\mathrm{MgCO}_{3} / \mathrm{PET}$ mixtures and b) $\mathrm{Mg}(\mathrm{OH})_{2} / \mathrm{PET}$ mixtures

\section{LITERATURE CITED}

1. Zhan, Y., Lin, J., Qiu, Y., Gao, N. \& Zhu, Z. (2011). Adsorption of humic acid from aqueous solution on bilayer hexadecyltrimethyl ammonium bromide-modified zeolite. Front. Environ. Sci. Engin. Chin. 5, 65-75. DOI: 10.1007/s11783-0100277-z.

2. Lesley, J., Flora, J.R.V., Park, Y., Badawy, M., Hazem, S. \& Yoon, Y. (2012). Removal of natural organic matter from potential drinking water sources by combined coagulation and adsorption using carbon nanomaterials. Sep. Purif. Technol. 95, 64-72. DOI: 10.1016/j.seppur.2012.04.033.

3. Huang, W.J. \& Yeh, H.H. (1999). Reaction of chlorine with NOM adsorbed on powdered activated carbon. Water Res. 33, 65-72. DOI: 10.1016/S0043-1354(98)00184-5.

4. Imyim, A. \& Prapalimrungsi, E. (2010). Humic acids removal from water by aminopropyl functionalized rice husk ash. $J$. Hazard. Mater. 184,775-781. DOI: 10.1016/j.jhazmat.2010.08.108.

5. Carlson, G. \& Silvestrain, J. (1997). Effect of ozonation on sorption of natural organic matter by biofilm. Water Res. 31, 2467-2478. DOI: 10.1016/S0043-1354(97)00106-1.

6. Anirudhan, T.S., Suchithra, P. S. \& Rijith, S. (2008). Amine-modified polyacrylamide-bentonite composite for the adsorption of humicacid in aqueous solutions. Colloids and Surf. A: Physicochem. Eng. Asp. 326, 147-156. DOI: 10.1016/j. colsurfa.2008.05.022.

7. Lorenc-Grabowska, E., Gryglewicz, G. (2005). Adsorption of lignite-derived humic acids on coal-based mesoporous activated carbons. J. Colloid Interface Sci. 284, 416-423. DOI: 10.1016/j.jcis.2004.10.031.

8. Lorenc-Grabowska, E. \& Gryglewicz, G. (2007). Adsorption characteristics of Congo Red on coal-based mesoporous activated carbon. Dyes Pigment. 74, 34-40. DOI: 10.1016/j. dyepig.2006.01.027.

9. Maghsoodloo, Sh., Noroozi, B., Haghi, A.K. \& Sorial, G.A. (2011). Consequence of chitosan treating on the adsorption of humic acid by granular activated carbon. J. Hazard. Mater. 191, 380-387. DOI: 10.1016/j.jhazmat.2011.04.096.

10. Mohanty, K., Das, D. \& Biswas, M.N. (2005). Adsorption of phenol from aqueous solutions using activated carbons prepared from Tectona grandis sawdust by $\mathrm{ZnCl}_{2}$ activation. Chem. Eng. J. 115, 121-131. DOI: 10.1016/j.cej.2005.09.016.

11. Kilic, M., Apaydin-Varol, E. \& Pütün, A.E. (2011). Adsorptive removal of phenol from aqueous solutions on activated carbon prepared from tobacco residues: Equilibrium, kinetics and thermodynamics. J. Hazard. Mater. 189, 397-403. DOI: 10.1016/j.jhazmat.2011.02.051.

12. Newcombe, G., Drikas, M. \& Hayes, R. (1997). Influence of characterized natural organic material on activated carbon adsorption: II. Effect on pore volume distribution and adsorption of 2- methylisoborneol. Water Res. 31, 1065-1073. DOI: $10.1016 / \mathrm{S} 0043-1354(96) 00325-9$.

13. Lin, J. \& Zhan, Y. (2012). Adsorption of humic acid from aqueous solution onto unmodified and surfactant-modified chitosan/zeolite composites. Chem. Eng. J. 200-202, 202-213. DOI: 10.1016/j.cej.2012.06.039.

14. Doulia, D., Leodopoulos, Ch., Gimouhopoulos, K. \& Rigas, F. (2009). Adsorption of humic acid on acid-activated Greek bentonite. J.Colloid Interface Sci. 340, 131-141. DOI: 10.1016/j.jcis.2009.07.028.

15. Wu, F.Ch., Tseng, R.L. \& Juang, R.S. (2002). Adsorption of dyes and humic acid from water using chitosan-encapsulated activated carbon. J. Chem. Technol. Biotechnol. 77, 1269-1279. DOI: $10.1002 /$ jctb. 705 .

16. Maghsoodloo, S., Noroozi, B., Haghi, A.K. \& Sorial, G.A. (2011). Consequence of chitosan treating on the adsorption of humic acid by granular activated carbon. J. Hazard. Mater. 191, 380-387. DOI: 10.1016/j.jhazmat.2011.04.096.

17. Moura, M.N., Martín, M.J. \& Burguillo, F.J. (2007). A comparative study of the adsorption of humic acid, fulvic acid and phenol onto Bacillus subtilis and activated sludge. $J$. Hazard. Mater. 149, 42-48. DOI:10.1016/j.jhazmat.2007.02.074.

18. Lai, C.H. \& Chen, C.Y. (2001). Removal of metal ions and humic acid from water by iron-coated filter media. Chemosphere 44, 1177-1184. DOI: 10.1016/S0045-6535(00)00307-6.

19. Chen, J.P. \& Wu, S. (2004). Simultaneous adsorption of copper ions and humic acid onto an activated carbon. J. Colloid Interface Sci. 280, 334-342. DOI: 10.1016/j.jcis.2004.08.029.

20. Velten, S., Knappe, D.R.U., Traber, J., Kaiser, H. P., Gunten, U., Boller M. \& Meylan, S. (2011). Characterization of natural organic matter adsorption in granular activated carbon adsorbers. Water Res. 45, 3951-3959. DOI: 10.1016/j. watres.2011.04.047.

21. Daifullah, A.A.M., Girgis, B.S. \& Gad, H.M.H. (2004). A study of the factors affecting the removal of humic acid by activated carbon prepared from biomass material. Colloids Surf. A 235, 1-10. DOI: 10.1016/j.colsurfa.2003.12.020.

22. Stárek, J., Zukal, A. \& Rathouský, J. (1994). Comparison of the adsorption of humic acids from aqueous solutions on active carbon and activated charcoal cloths. Carbon 32, 207-211. DOI: 10.1016/0008-6223(94)90184-8.

23. Morishita , T., Tsumura, T., Toyoda, M., Przepiórski, J., Morawski, A. W., Konno, H. \& Inagaki, M. (2010). A review of the control of pore structure in $\mathrm{MgO}$-templated nanoporous carbons. Carbon 48, 2690 -2707. DOI: 10.1016/j. carbon.2010.03.064.

24. Han, S., Kim, S., Lim, H., Choi, W., Park, H., Yoon, J. \& Hyeon, T. (2003) New nanoporous carbon materials with high 
adsorption capacity and rapid adsorption kinetics for removing humic acids. Microporous Mesoporous Mater. 58, 131-135. DOI: 10.1016/S1387-1811(02)00611-X.

25. Yue, Z., Mangun, C.L. \& Economy, J. (2004). Characterization of surface chemistry and pore structure of $\mathrm{H}_{3} \mathrm{PO}_{4}$ -activated poly(vinyl alcohol) coated fiberglass. Carbon 42, 1973-1982. DOI: 10.1016/j.carbon.2004.03.030.

26. Tamai, H., Yoshida, T., Sasaki, M. \& Yasuda, H. (1999). Dye adsorption on mesoporous activated carbon fiber obtained from pitch containing yttrium complex. Carbon 37, 983-989. DOI: 10.1016/S0008-6223(98)00294-2.

27. Davini, P. (2001). $\mathrm{SO}_{2}$ and $\mathrm{NO}_{\mathrm{x}}$ adsorption properties of activated carbons obtained from a pitch containing iron derivatives. Carbon 39, 2173-2179. DOI: 10.1016/S00086223(01)00035-5.

28. Nakagawa, K., Mukai, S.R., Suzuki, T. \& Tamon, H. (2003). Gas adsorption on activated carbons from PET mixtures with a metal salt. Carbon 41 (2003) 823-831. DOI: 10.1016/ S0008-6223(02)00404-9.

29. Przepiórski, J., Karolczyk, J., Takeda, K., Tsumura, T., Toyoda, M. \& Morawski, A. W. (2009). Porous Carbon Obtained by Carbonization of PET mixed with basic magnesium carbonate: Pore Structure and Pore Creation Mechanism. Ind. Eng. Chem. Res. 48, 7110-7116. DOI: 10.1021/ie801694t.

30. Karolczyk, J., Janus, M. \& Przepiórski, J. (2012). Removal of model contaminants from water by porous carbons obtained through carbonization of poly(ethylene terephthalate) mixed with some magnesium compounds. J. Porous Mater. DOI: 10.1007/s10934-012-9585-y.

31. Czyżewski, A., Karolczyk, J., Usarek, A. \& Przepiórski, J. (2012). Removal of two ionic dyes from water by MgOloaded porous carbons prepared through one-step process from poly(ethylene terephthalate)/ magnesium carbonate mixtures. Bull. Mater. Sci. 35, 211-219.

32. Przepiórski, J., Karolczyk, J., Tsumura, T., Toyoda, M., Inagaki, M.\& Morawski, A.W. (2011). Effect of some thermally unstable magnesium compounds on the yield of char formed from poly(ethylene terephthalate). J. Therm. Anal. Calorim. 107 (3), 1147-1154. DOI 10.1007/s10973-011-1910-1.

33. Yorgun, S., Vural, N. \& Demiral, H. (2009). Preparation of high-surface area activated carbons from Paulownia wood by $\mathrm{ZnCl}_{2}$ activation. Microporous Mesoporous Mater. 122, 189-194. DOI: $10.1016 /$ j.micromeso.2009.02.032.

34. Hared, I.A., Dirion, J.L., Salvador, S., Lacroix, M., Rio, S. (2007). Pyrolysis of wood impregnated with phosphoric acid for the production of activated carbon: Kinetics and porosity development studies. J. Anal. Appl. Pyrolysis 79, 101-105. DOI: 10.1016/j.jaap.2006.12.016.

35. Tham, Y.J., Latif, P.A., Abdullah, A.M., Shamala-Devi, A. \& Taufiq-Yap, Y.H. (2011). Performances of toluene removal by activated carbon derived from durian shell. Bioresour. Technol. 102, 724-728. DOI: 10.1016/j.biortech.2010.08.068.

36. Bansode, R.R., Losso, J.N., Marshall, W.E., Rao, R.M. \& Portier, R.J. (2004). Pecan shell-based granular activated carbon for treatment of chemical oxygen demand (COD) in municipal wastewater. Bioresour. Technol. 94, 129-135. DOI: 10.1016/j.biortech.2003.12.009.

37. Inagaki, M., Kato, M., Morishita, T., Morita, K. \& Mizuuchi, K. (2007). Direct preparation of mesoporous carbon from a coal tar pitch. Carbon 45, 1121-1124. DOI: 10.1016/j. carbon.2007.01.014. DOI: 10.1016/j.jpowsour.2007.09.042.

38. Fernández, J.A., Morishita, T., Toyoda, M., Inagaki, M., Stoeckli, F. \& Centeno, T.A. (2008). Performance of mesoporous carbons derived from poly(vinyl alcohol) in electrochemical capacitors. J. Power Sources 175, 675-679. DOI: 10.1016/j. jpowsour.2007.09.042.

39. Peuravuori, J., Koivikko, R. \& Pihlaja, K. (2002). Characterization, differentiation and classification of aquatic humic matter separated with different sorbents: synchronous scanning fluorescence spectroscopy. Water Res. 36, 4552-4562. DOI: 10.1016/S0043-1354(02)00172-0.

40. Uyguner, C.S. \& Bekbolet, M. (2005). Evaluation of humic acid photocatalytic degradation by UV-vis and fluorescence spectroscopy. Catal. Today 101, 267-274. DOI: 10.1016/j. cattod.2005.03.011.

41. Pelekani, C., Snoeyink, V.L. (1999). Competitive adsorption in natural water: role of activated carbon pore size. Water Res. 33, 1209-1219. DOI: 10.1016/S0043-1354(98)00329-7.

42. Mui, E.L.K., Cheung, W.H., Valix, M. \& McKay, G. (2010). Dye adsorption onto activated carbons from tyre rubber waste using surface coverage analysis. J. Colloid Interface Sci. 347, 290-300. DOI: 10.1016/j.jcis.2010.03.061.

43. Yuan, X., Zhuo, S.-P., Xing, W., Cui, H.-Y., Dai, X.-D., Lui, X.-M. \& Yan, Z.-F. (2007). Aqueous dye adsorption on ordered mesoporous carbons. J. Colloid Interface Sci. 310, 83-89. DOI: 10.1016/j.jcis.2007.01.069.

44. Tryba, B., Brożek, P., Piszcz, M. \& Morawski, A.W. (2011). New photocatalyst for decomposition of humic acids in photocatalysis and photo-Fenton processes. Pol. J. Chem. Technol., 13, 08-14. DOI: 10.2478/v10026-011-0042-5.

45. Chen, J., LeBoeuf, E.J., Dai, S. \& Gu, B. (2003). Fluoresence spectroscopic studied of natural organic matter fractions. Chemosphere 50, 639-647. DOI: 10.1016/S0045-6535(02)00616-1.

46. Fasurová, N., Čechlovská, H. \& Kučerík, J. (2006). A comparative study of South Moravian lignite and standard IHSS humic acids, optical and colloidal properties. Pet. Coal. $48,24-32$. 